\title{
Utilization of School Learning Discipline to Internalize the Multicultural Value of Early Childhood in Paud Karuna Dipa Palu
}

\author{
Author: Kasmiati \\ Affiliation: Palu State Islamic Institute \\ E-mail: Kasmiatiridha78@gmail.com
}

\begin{abstract}
The purpose of this research is to find and explain the utilization of school learning discipline in PAUD Karuna Dipa Palu as a means to internalize multicultural values. With the qualitative phenomenological research method that focuses on researching the introduction and implementation of learning disciplines, it was found that PAUD
\end{abstract} Karuna Dipa Palu was able to utilize school learning discipline $g$ to internalize multicultural values. Learning discipline in school is conducted through three essential stages, i.e., the transformation of multicultural value, multicultural value transaction, and trans-internalization of multicultural value. These three internalization stages are carried out in two essential activities: introducing school learning discipline directly to students and introducing learning discipline involving parents. In this way, this school learning discipline, multicultural values of justice, equality, and responsibility can be internalized in PAUD Karuna Dipa Palu students. Keywords: school learning dicipline, internalization of multicultural values, and early childhood.

\section{INTRODUCTION}

Indonesia is a multicultural country with a population of more than 270 million people. One aspect of multiculturalism is religion. Indonesian embraced six religions: Islam (87.18 \%), Protestantism (6.96\%), Catholic Christianity (2.91 $\%)$, Hinduism (1.69\%), Buddhism (0.72\%), and Kong $\mathrm{Hu} \mathrm{Chu}(0.05 \%)$ with various faith streams in it. Indonesia also has 370 ethnic groups that use 67 parent languages with thousands of distinctive dialects (Dwidjowidjoto, 2019). This reality of diversity places Indonesia as the multicultural country with the most diversity in the world (Yaqin, 2007). Therefore, a multicultural Indonesian is an important wealth that must be maintained and managed properly. The goal is for multiculturalism to unify nations in different religions, ethnicities, cultures with various other socio-cultural backgrounds (Arfa, 2018). Without a good spirit of care, multiculturalism can be a potential conflict, divisive of community unity (Machmud, 2018; Minarso, 2021).

From here, it is necessary to develop the spirit of multiculturalism in each individual through educational institutions because only with education is the process of internalizing this multicultural spirit in students can be done well. One of the appropriate educational institutions in internalizing this multicultural spirit is the early childhood education unit (Cahyono and Susanti, 2019). It happens because the early childhood education unit focuses on providing educational services from an early age. Educational service is 
conduct in science, skills, and attitudes or character (Deiniatur, 2016). Early childhood education institution is the proper medium to internalize multicultural values because (1) character education is the one of focus in early childhood education so that multicultural values can be the basis of character education, and (2) early childhood education educates children from an early age so that the internalization of multicultural values can be instilled in children since early stage.

Internalization of multicultural values in early childhood is internalized multicultural values from an early stage so that the multicultural generation is being prepared well. The generation that has a worldview on the importance of respecting and respecting cultural differences and readiness to accept differences from other groups or communities (Rahman, 2011). With an excellent multicultural education, the community will believe that the life of its substance is to maintain harmony and unity in seeing the differences between cultures, ethnicities, genders, languages, and religions (Azra, 2007). A generation multicultural society is a society that sees that every individual has the same right to-perceive differences, both in public and private areas (Yaqin, 2007). Therefore, generation and society will represent diversity and affirm that all differences have equal rights in public spaces in state life (Iswanto, 2015).

Early childhood education is also the most appropriate and robust means and foundation in internalizing the value of multiculturalism (Fransiska, 2018). It is based on the perspective that learning multiculturalism is learning to understand reality, introduce cultural diversity, and appreciate the differences in society (Hasanah, 2018). Education in internalizing multicultural values in early childhood can then realize generations and multiculturalism society. From here, the basis of multicultural education for early childhood is necessary to internalize multicultural values in students oriented to provide justice, equality, and freedom in respecting ethnic, racial, religious, and social classes (Sinagatullin, 2013). Education in internalizing multicultural values teaches democracy, freedom, and respect for different human rights (Musi, 2019 and Rosaydi, 2019). Thus, education becomes a means to internalize multicultural values in learners. Children from an early age have a multicultural character, making children from an early age appreciate the differences and diversity in the community (Hermino, 2014).

Multicultural value education will shape learners into an individual with multicultural character. There are always activities that can sublime values and characters to students in shaping attitudes and behaviors (Zakiyah, 2014). Theodore Bramelt in Zaim Elmubarok (2013) explains that the philosophy of multicultural value education is an education that can be a place or intermediary in providing the cultivation of multicultural values contained in learners. The urgency of internalizing these multicultural values is based on the view that the child's character can be shaped by the believed multicultural values (Imamah and Jumhuri, 2020).

Internalizing multicultural values strategy can be carried out through education by implementing the learning discipline in the proper education in schools for an early age. It happens because the discipline in learning is one of these educational activities appropriate in conditioning early childhood to learn well and understand the value of character well in words and deeds. Moreover, it follows early childhood development in the stage of absorbing value (Helmawati, 2015). 
Therefore, implementing multicultural education's value by applying the school learning discipline in early childhood can internalize multicultural values in early childhood learning activities.

One of the early childhood education institutions (PAUD) that implement and utilize school learning discipline to internalize multicultural values is PAUD Karuna Dipa Palu. The students are heterogeneous in religion, ethnicity, culture, and gender. Karuna Dipa Foundation organizes disciplinary utilization activities early childhood education activities to internalize multicultural values. Utilizing the school learning discipline in internalizing multicultural values can also succeed, namely, effectively internalizing multicultural values in early childhood. No wonder PAUD Karuna Dipa Palu is a foundation with Buddhist identity in the middle of Palu City, majority Muslim. From here, multicultural education with the internalization of multicultural values becomes the basis of organizing education to create harmony between learners and teachers of various religions.

Internalizing multicultural values in early childhood to students using school learning discipline can create children and parents with an excellent multicultural spirit. It is evidenced by the differences in religious, ethnic, cultural, and gender identity in educational institutions that can be upheld, respected, and appreciated. Thus, harmony is created well in educational institutions PAUD Karuna Dipa Palu. Therefore, this study will review and expose facts related to the utilization of school learning disciplines conducted by PAUD Karuna Dipa Palu in internalizing multicultural values in early childhood learners.

\section{METHOD}

This research was conducted at PAUD Karuna Dipa Palu located on Jl. Sungai Lariang No. 21 Nunu, West Palu District, Palu City. This study examines the utilization of school learning discipline in internalizing multicultural values in PAUD Karuna Dipa Palu. The utilization of school learning discipline in internalizing multicultural values is examined from an educational perspective based on multiculturalism (Suriasumantri, 1998). The steps of critically analytical research include: (1) Describing and discussing the concept of utilization of learning discipline at PAUD Karuna Dipa Palu. This discussion has been conducted based on interpreting the concept of learning discipline to internalize multicultural values in learning. Description and discussion process by explaining the various practices of the utilization of discipline in learning activities, then providing interpretation by connecting, associating and confronting or communicating various concepts in one complete study; (2) criticize the process of utilizing the discipline of learning in internalizing the multicultural value of learning using a multicultural educational perspective; and (3) submit conclusions of findings and reflections on the utilization of learning disciplines in educational activities to internalize multicultural values in early childhood.

The research instruments are accurately arranged to obtain the required data (Usman, 2000). The research instruments used are: first, observations in research conducted by observing objects to be examined and collecting as much data or information as possible (Rohidi, 2002). The object observation is the utilization of school learning discipline activities to internalize multicultural values in early childhood. Second, the interview was conducted by asking teachers and 
students related to research issues, namely the utilization of school learning disciplines to internalize the value of multicultural education in early childhood learners (Surakhmad, 2005). Third, documentation of data retrieval through documentation in drawings and learning documents such as learning journals, schedules of learning activities, and student journals (Moleong, 2015).

In the processing of data in researchers using qualitative methods, namely data processed by selecting various data, then classified based on the study subjects, which is then held interpretation of the data (Hubberman, 2015). Data analysis is done by data reduction, data classification, and data verification. Checking the validity of this data is used to know the validity of the data obtained to determine the data's validity (trustworthiness) of the required examination techniques. The implementation of the inspection technique is based on a certain number of criteria. This study is used to be stimulated through sources, which means comparing the results of interviews with observations, comparing what informants say about the situation of the study with the results of extended participation by researchers, and comparing the results of interviews with school documents and their implementation. With this technique, comprehensive data will be obtained to find findings related to the internalization of multicultural values in early childhood learning at PAUD Karuna Dipa Palu..

\section{DISCUSSION}

The process of internalizing multicultural values in the learning of PAUD Karuna Dipa Palu can be mapped in three essential stages: first, the stage of value transformation, at this stage formulated the process carried out by the teacher and confirm the good values and bad grades, at this stage communication only occurs between the teacher and the students or students guidance. In symbolic interactionism, human acts according to the meanings obtained from the results of interactions with others. The meaning is refined from the ongoing interaction process on an ongoing basis. Multicultural values are also symbolic meanings that play a role in shaping behavior. The teacher must initially explain those meanings to the learners to have an initial description of the understanding of multicultural values as symbolic meanings (Abdurrahmansyah, 2017). This explanation does not always have to be in defining and explaining the meaning of multicultural values. However, it can also be concrete examples, even actual behaviors seen and experienced directly by learners. The learners will understand multicultural values from the actual behavior seen and experienced directly by the learners (Arif, 2019).

The second, the value transaction stage. At this stage, communication can be done in two directions, or there is an interaction between teachers and students. In this context, multicultural values as symbolic meanings are further refined by learners in shaping their behavior (Banks, 2000). These enhancements can be positive reinforcement to improve the internalization of values, negative reinforcement to correct and eliminate misapprehending values, or punishment to eliminate behavior contrary to multicultural values (Grant Carl, 2009).

Third, the trans-internalization stage. Communication plays an active role because it is much more profound than the value transaction stage. After all, it is not only verbal communication that is prioritized but also mental attitudes and personalities. In this context, multicultural values as symbolic meanings are increasingly understood by learners, and even learners form their 
understanding of these values through interactions with people around them (Banks, 2000).

These three dimensions do not take place gradually or step by step but are simultaneously interconnected and integrated and strengthen each other. In the learning process, teachers directly involve students interactively as value transactions, followed by informing the learning content as a value transformation, or vice versa. Along with that, trans-internalization of values is also integrated by teachers to get used to performing certain behaviors that fit multicultural values. Because there are no indicators of spiritual attitudes and attitudes, nor are indicators of multicultural values set in learning planning. Internalizing multicultural values go hand in hand integrally with all learning processes and interconnected without conceptualizing multicultural values. Students are expected to conceptualize their knowledge of multicultural values following the learning experience gained. It takes place in all learning activities at PAUD Karuna Dipa Palu. One aspect of educational activities in PAUD Karuna Dipa Palu that is used as an activity to internalizes multicultural values in early childhood is the School Learning Discipline. In addition, PAUD Karuna Dipa Palu utilizes the School Learning Discipline to internalize multicultural values. There are three identifiable values: responsibility, fairness, and equality. The process of internalizing multicultural values is presented in the following table.

\section{The Process of Internalizing Multicultural Values in the School Learning Discipline PAUD Karuna Dipa Palu}

\begin{tabular}{|c|c|c|c|c|}
\hline No. & Value Type & Value Transformation & Value Transaction & $\begin{array}{l}\text { Trans-Internalization } \\
\text { Values }\end{array}$ \\
\hline 1 & 2 & 3 & 4 & 5 \\
\hline 1. & Responsibility & $\begin{array}{l}\text { Invite and involve learners } \\
\text { to repeat the reading of the } \\
\text { content of the school } \\
\text { learning discipline }\end{array}$ & $\begin{array}{l}\text { Teachers apply school } \\
\text { learning discipline to } \\
\text { students in a disciplined } \\
\text { manner }\end{array}$ & $\begin{array}{l}\text { Students responsibly carry } \\
\text { out disciplinary education, } \\
\text { and teachers only supervise } \\
\text { the course of the school } \\
\text { learning discipline }\end{array}$ \\
\hline 2 & Fairness & $\begin{array}{l}\text { The teacher informs that } \\
\text { the school learning } \\
\text { discipline will be applied to } \\
\text { all students without } \\
\text { exception. }\end{array}$ & $\begin{array}{l}\text { Teachers with praise } \\
\text { appreciate students who } \\
\text { carry out school } \\
\text { learning discipline. } \\
\text { However, the teacher } \\
\text { consistently reprimands } \\
\text { students who violate the } \\
\text { discipline. }\end{array}$ & $\begin{array}{l}\text { Students are conditioned to } \\
\text { carry out school learning } \\
\text { discipline and be enforced } \\
\text { fairly }\end{array}$ \\
\hline 3. & Equality & $\begin{array}{l}\text { The teacher tells all } \\
\text { students to be equal, and } \\
\text { nothing is different. All are } \\
\text { obliged to adhere to the } \\
\text { school learning discipline }\end{array}$ & $\begin{array}{l}\text { Teachers give } \\
\text { transparency in applying } \\
\text { learners equally in the } \\
\text { application of school } \\
\text { learning discipline }\end{array}$ & $\begin{array}{l}\text { Students want to be } \\
\text { enforced just like other } \\
\text { learners without feeling } \\
\text { exaggerated or demeaned }\end{array}$ \\
\hline
\end{tabular}


Volume 9 Issue 5 May 2021

Internalizing the values of responsibility in PAUD

Karuna Dipa Palu students is a problem because early childhood began to realize their desires and encouraged them to satisfy their desires at the age of two. At this stage, the child begins to be physically and psychologically independent, feeling a free person and not part of others. This condition affects obedience, so it often shows disobedience and refuses the orders of others. If early childhood finds norms and rules that are not following their wishes, then the child tends not to obey them (Cram, 2014). However, this noncompliance should not be left alone because it will be a way of life that becomes negative behavior in the future if not handled properly. Here, the discipline of learning then organizes and overcomes the problem so that the child can be organized back in respecting and appreciating friends in their learning activities. Thus, the value of responsibility can be internalized in the learner.

On the other hand, early childhood learns by imitating (mimises) (Hurlock, 2006). The characteristics of early childhood learning are used as a learning modality by PAUD Karuna Dipa Palu teachers by inviting children to imitate teachers in transacting the values of responsibility, fairness, and equality through school learning discipline in learning. The teacher will inform the children about school learning discipline by speaking loudly repeatedly, moving the body, and singing, followed by the learners.

For example, when the school's learning discipline is read out in front of students, and they are asked to follow it together aloud repeatedly. Teachers read it in a fun way, namely by following the teacher's intonation, expression, and teacher movements. For example, when the teacher mentions all students must come 10 minutes before the lesson starts, then the teacher will lift ten fingers while waving his hands and followed by all students, then lift one index finger to remind the learners not to be late. Likewise, when the discipline is read that all students are obliged to dress in clean and neat uniforms, the students follow the teacher, hold the clothes then imitate cleaning and ironing motion. Using shoes is practiced by lifting the right foot and left foot alternately, pointing the foot to hint using shoes, etc. This activity will end with a round of applause and spinning or dancing (Results of Interview with Teacher).

The way to inform the school learning discipline always organizes students and teachers to be directly involved in understanding the rules in the discipline adapted to the world of learners, namely moving and playing interactively. Then, it will be easy to remember, and students will obey the discipline. From here, school learning discipline becomes a means of internalizing the values of responsibility, fairness, and equality delivered by involving learners directly in the learning activities. For that reason, there is a process of value transformation and value transactions that run synergistically that directly internalize multicultural values in students (Banks, 2000).

There is no specific guide that requires teachers to follow one particular way of teaching learners the school learning discipline. All methods and strategies are left to the creativity of the teacher. The dimension of trans-internalization of the value of responsibility, fairness, equality through school learning discipline goes hand in hand with value transformation and trans-internalization of values (Junanto and Latifah, 2020). For example, the transformation of disciplinary values applied by PAUD Karuna Dipa Palu teachers is not done hard and rigidly, but also not too flexible, which causes students to underestimate the discipline. Students 
Volume 9 Issue 5 May 2021

who obey the rules will be rewarded with praise and flattery, while students who break the rules will be reminded consistently. Corporal punishment is avoided because it causes learners to fight in their way. If continuously left behind, it will become a sedentary behavior that becomes the habit of his life to be responsible and obey the rules (Results of Interviews with Teachers).

Thus, students will understand that they will be enforced equally and fairly in the learning process and learn discipline in living the existing rules without the need for teachers to inform the understanding of equality and discipline. Students are susceptible to unfair treatment, so teachers emphasize that they will enforce this discipline fairly without discriminating. The consistency of teachers to keep reminding students is the key to the success of the transformation of the value of responsibility on school learning discipline in PAUD Karuna Dipa Palu, not on the coercion of rules that students will oppose. For example, students caught carrying toys from home are asked to hand over the toys to a parent/guardian who takes them to school with gentle persuasion while being reminded that they have broken the rules. The establishment of the value of responsibility in learning the school learning discipline in students will depend heavily on implementing such disciplines fairly and equally. Implementing unfair and unequal discipline and tends to discriminate will create inconsistencies in teachers in applying norms. The learner will confuse because they see their friend is not the same as themselves when violating the discipline or is not appreciated with praise when they are obedient to the discipline. Students will take the initiative to imitate their friends by violating the school learning discipline. In other words, internalizing the values of responsibility must also be supported by internalizing the values of fairness and equality to strengthen each other. It is what Banks (2000) intended with the dimension of equality in education (an equity pedagogy), which is learning that shapes the perception of learners of equal rights and equality to gain learning opportunities in a multicultural school environment (Kusuma, 2013).

In transforming the value of responsibility, PAUD Karuna Dipa Palu teachers emphasize more on collaboration with parents/guardians of students. Therefore, parents /guardians are also reminded to obey the discipline of learning in school by having to do activities: (1) getting students to do their activities, such as carrying their bag and taking off the shoes and tidying them; (2) take the learner 10 minutes before the lesson start and pick up the learner 10 minutes after the lesson is finished; (3) waiting for the students in a proper place; (4) not permissible to wait in the classroom during lesson hours; (5) not sitting on the children's play tool; (6) maintain the cleanliness of the school environment; (7) payment on time; (8) dressed neatly; and (9) participate in school activities (Results of Interviews with Teachers).

Collaboration is essential to create consistency between teachers and parents in providing learning to students to obey rules and norms. Banks called this involvement (2000) is the empowerment of school culture and social structure involving learners, teachers, and community interactions. In this case, parents-guardians build multicultural awareness to create an academic culture that supports the internalization of multicultural values in learners. The school provides similarity to all student differences and ensures that all teachers, students, and the community actively participate.

Indicators of the successful learning of discipline in school related to the internalization of multicultural 
Volume 9 Issue 5 May 2021

values result from learning through school learning discipline indicated by trans-internalization of values.

1) In the dimension of the value of responsibility, the behavior of learners is formed responsibly carrying out the discipline, and the teacher only supervises the course of the discipline. Students who are getting used to obeying the discipline are seen as starting to form the value of responsibility.

2) The fairness value dimension, behavior of learners, is formed in a manner that is conducted in a disciplined manner because the school learning discipline is enforced fairly. Therefore, students begin to accept adherence to the norms of discipline because they see it as fair enforced when they obey or violate the school learning discipline. Thus, it is seen that the value of fairness has begun to form.

3) In the dimension of equality, students want to be enforced just like other learners without feeling exaggerated or demeaned. This indicator is the same as in the value of fairness.

I can be done through school learning discipline.

This school learning discipline is related to the rules or steps that students must participate in learning activities. The school learning discipline at PAUD Karuna Dipa Palu teaches three essential values: responsibility, fairness, and equality. Through these three values of school learning discipline, internalization of values is carried out in students. The internalization process is carried out by introducing and teaching the discipline of learning directly by PAUD Karuna Dipa Palu teachers to students through various creative methods following the teacher's abilities. This method effectively makes students understand the school learning discipline and can condition the learners to implement in learning activities. Parents are also involved in obeying school learning discipline that with the obedience of these parents, the learners get understanding from the parents. In these two ways, the value of responsibility, fairness, and equality as the content of multicultural value is internalized in PAUD Karuna Dipa Palu students.

\section{CONCLUSION}

PAUD Karuna Dipa Palu is a multicultural early childhood education institution because it can build a spirit of mutual respect between students, teachers, and parents of different religions. This multicultural attitude was formed because of the success of PAUD Karuna Dipa Palu in developing learning oriented to the internalization of multicultural values. One of the learning concepts developed is school learning discipline conducted through three essential stages: multicultural value transformation, multicultural value transactions, and trans-internalization of multicultural values. These three stages of internalization are carried out in two essential activities: first, the introduction of learning discipline by teachers directly to the students. The introduction activities conducted creatively and interestingly following the development of children make students easily understand and implement the school learning discipline. Second, the introduction of school learning discipline involving parents. Parents are also directly introduced to the school learning discipline. In this way, parents will also teach children or students to be more understanding and active in practicing it. Through this school learning discipline, the multicultural values of responsibility, fairness, and equality can be internalized in PAUD Karuna Dipa Palu students. 
Volume 9 Issue 5 May 2021

\section{REFERENCES}

Arfa, Arman Man. 2018. "Pendidikan PAUD

Berbasis Multikultural" dalam Dialektika: Jurnal Pemikiran Islam dan Ilmu Sosial Vol. 11, No. 02 Oktober 2018.

Arif, Andika Aprilianto dan Muhammad. 2019. "Pendidikan Islam dan Tantangan Multikultural: Tinjauan Filosifis" dalam Jurnal Nazhruna : Jurnal Pendidikan Islam, Vol. 2 No. 2, 2019.

Abdurrahmansyah. $2017 . \quad$ "Pendidikan Multikultural dalam Desain Kurikulum dan Pembelajaran Keagamaan Islam" dalam Jurnal Madania: Jurnal Kajian Keislaman, Vol.21, No.1, 2017.

Azra, Azumardi. 2007. Merawat Kemajemukan Merawat Indonesia. Yogyakarta: Kanisuius.

Banks, James A. 2000. Multicultural Education: Theory and Practice. New York: Allyn and Bacon.

Cram, Penny Hauser- et al. 2014. Development of Children and Adolescents, Kendalville, John Wiley \& Sons,

\section{-}

Elmubarok, Z. 2013. Membumikan Pendidikan Nilai: Mengumpulkan yang Terserak, Menyambungkan yang Terputus dan Menyatukan yang Tercerai. Bandung: Alfabeta.

Cahyono, Heri dan Yeni Susanti. 2019. "NILAINILAI PENDIDIKAN MULTIKULTURAL DALAM FILM ANIMASI UPIN IPIN EPISODE ESOK HARI RAYA, GONG XI FA CAI, DAN DEEPAVALI" dalam Jurnal At-tajid: Pendidikan dan Pemikiran Islam Vol 3, No 01 (2019).

Deiniatur, Much. 2016. "Implementasi Pendidikan Multikultural pada Anak-Anak Melalui Model Pembelajaran Bermain Peran" dalam Jurnal Thufula Vol 4, No 1 (2016).
Dwidjowidjoto, Riant Nugroho, 2020. Indonesia 2020: Sebuah Sketsa tentang Visi dan Strategi dalam Kepemimpinan Manajemen Politik dan Ekonomi. Jakarta: RBI Research.

Fransiska. 2018. "Menumbuhkan Nilai-nilai Pendidikan Multikultural di TK Graha Mulia Sintang" dalam DUNIA ANAK: Jurnal Pendidikan Anak Usia Dini, 1 (1), Mei 2018.

Grant Carl A., et.al.. 2009. Intercultural Education and Multicultural Education: Enhancing Global Interconnectedness. USA: Routledge.

Hasanah, Uswatun. 2018. "Implementasi Pendidikan Multikultural dalam Membentuk Karakter Anak Usia Dini” dalam Jurnal Golden Age: Jurnal Pendidikan Anak Usia Dini, Vol. 2, No. 1 (Juni 2018).

Helmawati 2015. Mengenal dan Memahami PAUD. Bandung: Remaja Rosdakarya.

Hermino, A. (2014). Manajemen Kurikulum Berbasis Karakter: Konsep, Pendekatan, dan Aplikasi. Alfabeta.

Huberman, M. B. M. dan A. M. 2009. Analisis Data Kualitatif. Terj. Tjetep Rohendi Rohidi. Jakarta: UI Press.

Hurlock, Elisabeth. 2006. Perkembangan Anak. Terj. Meitasari Tjandras dan Muchlihan Zarkasih. Jakarta: PT. Gelora Aksara Pratama.

Imamah, Nurul dan M. Jamhuri. 2020. "REINFORCEMENT PENDIDIKAN MULTIKULTURAL BAGI ANAK (Studi Multisitus di TK Ceria dan TK Golden Kids Pandaan)" dalam Journal MULTICULTURAL of Islamic Education Volume 4 Nomor 1 Oktober 2020. 
Volume 9 Issue 5 May 2021

Iswanto, Agus. 2007. 2015. "Integrasi PAI dan

PKN: Mengupayakan PAI yang Berwawasan Multikultural," dalam Zainal Abidin EP, Pendidikan Agama Islam dalam Perspektif Multikulturalisme. Badan Penelitian dan Pengembangan Agama.

Junanton, Subar dan Latifah Permatasari Fajrin. 2020. "Internalisasi Pendidikan Multikultural pada Anak Usia Dini” dalam Jurnal Pendidikan Anak Usia Dini Undiksha Vol. 8 (1), pp. 28-34, 2020.

Kusuma, Wira Hadi. 2013. "Urgensi Pendidikan Multikultural bagi Anak Usia Dini” dalam Jurnal Bahasa Vol 2, No 1 (2013).

Machmud, Hadi dan Nur Alim. 2018. "Multicultural Learning Model of PAUD in Coastal Areas" dalam Jurnal Obsesi : Jurnal Pendidikan Anak Usia Dini Volume 2 Issue 2 (2018) Pages 170 - 182.

Minasaro, Arofah, dkk. 2021. "Perkenalan Dunia Internasional sebagai Pendidikan Multikutural pada Anak Usia Dini melalui Metode Bermain Puzzle" dalam Jurnal Obsesi : Jurnal Pendidikan_Anak Usia Dini, Volume 5 Issue 2 (2021) Pages 2124-2133.

Moleong, L. J. 2001. Metodologi Penelitian Kualitatif. PT Remaja Rosdakarya.

Musi, Muhammad Akil Musi dan Parwoto. 2019. "Pembelajaran Multikultural Anak Usia Dini Berbasis Kearifan Lokal" dalam PROSIDING SEMINAR NASIONAL LP2M UNM - 2019 "Peran Penelitian dalam Menunjang Percepatan Pembangunan Berkelanjutan di Indonesia”
Qiqi Yuliati, Zakiyah, E. al. (2014). Pendidikan

Nilai: Kajian Teori dan Praktik di Sekolah. Pustaka Setia.

Rahman Abdul., dkk. 2011. Panduan Integrasi Nilai Multikultural dalam Pendidikan Agama Islam pada SMA dan SMK. AGPA II.

Rohidi. 2002. Metode Penelitian Kualitatif. Bandung: Alfabeta.

Rosyadi, Ali Miftakhu. 2019. "Implementasi Nilainilai Multikulturalisme Melalui Pembelajaran Pendidikan Agama Islam" dalam Risâlah, Jurnal Pendidikan dan Studi Islam Vol 5 Nomor 1 MAret 2019 .

Sinagatullin, I. M. 2003. Constructing Multicultural Education in a Diverse Society. A Scarecrow Education Book.

Surakhmad, W. 2005. Pengantar Penelitian Ilmiah. Bandung: Tarsito.

Suriasumantri, J. S. 1998. "Penelitian Ilmiah, Kefilsafatan dan Keagamaan: Mencari Paradigma Kebersamaan," dalam Mastuhu dan M. Deden Ridwan (Ed.), Tradisi Baru Penelitian Agama Islam: Tinjauan Antardisiplin Ilmu. Nuansa dan Pusjarlit.

Usman, Husaini A., dkk. 2000. Metode Penelitian Sosial. Bandung: Bumi Aksara.

Yaqin, M. A. 2007. Pendidikan Multukultural: Cross-Cultural Understanding untuk Demokrasi dan Keadilan. Pilar Media. 